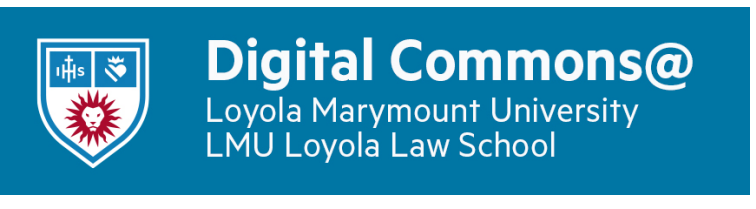

Journal of Catholic Education

Volume 10 | Issue 1

Article 6

$9-1-2006$

\title{
What I Overheard in the Sesquicentennial Conversation
}

Una M. Cadegan

Follow this and additional works at: https://digitalcommons.Imu.edu/ce

\section{Recommended Citation}

Cadegan, U. M. (2006). What I Overheard in the Sesquicentennial Conversation. Journal of Catholic Education, 10 (1). http://dx.doi.org/10.15365/joce.1001062013

This Focus Section Article is brought to you for free with open access by the School of Education at Digital Commons at Loyola Marymount University and Loyola Law School. It has been accepted for publication in Journal of Catholic Education by the journal's editorial board and has been published on the web by an authorized administrator of Digital Commons at Loyola Marymount University and Loyola Law School. For more information about Digital Commons, please contact digitalcommons@lmu.edu. To contact the editorial board of Journal of Catholic Education, please email JCE@nd.edu. 


\title{
FOCUS SECTION
}

\section{WHAT I OVERHEARD IN THE SESQUICENTENNIAL CONVERSATION}

\author{
UNA M. CADEGAN \\ University of Dayton
}

Catholic higher education is in many ways still responding to the challenge first articulated by John Tracy Ellis in his 1955 essay. In efforts to promote both a unique Catholic identity and a culture of excellence on par with secular institutions, Catholic universities can learn much from their historical context, founding religious communities, and contemporary experience. This essay suggests some practical applications for campus life and governance that might be culled from a university's religious history.

W Then, in the year 2000, the University of Dayton celebrated its 150th anniversary, then-university president Brother Raymond L. Fitz, S.M., convened a sesquicentennial conversation on the Catholic and Marianist character of the university. All units of the university, academic and non-academic, were asked to hold department-level discussions around several questions concerning the Catholic and Marianist character of the university: how people understood the university as Catholic and Marianist, what they found exciting or frustrating about it, and what needed to be clarified. These conversations were summarized by department, and the results were forwarded to the president by the respective deans and vice presidents.

To reflect on the results of the Sesquicentennial Conversation and make recommendations to strengthen and renew the university's Catholic and Marianist character, Brother Fitz appointed a 25-member task force comprised of members from all divisions of the university. He asked me to cochair the task force along with Father Gene Contadino, S.M., then rector of the university. The task force met for more than 2 years, reflected on the results of the conversation, formulated a draft report with recommendations, and invited campus-wide comment on them. The report was revised in light of the campus response to the draft and submitted to Brother Fitz during a chapel prayer service held as part of the university's annual Marianist Heritage Celebration in February 2002. The task force report is entitled "Conversing: Reflections on the University of Dayton's Catholic and 
Marianist Character in its 150th Year-A Report from the Task Force on the Sesquicentennial Conversation" (University of Dayton, 2002). Nothing in the present account should be taken as a criticism of what the task force produced. The report both captured some of the important aspects of the campus-wide conversation and advanced the discussion by pressing more specifically some issues that had not been foregrounded as clearly in earlier such documents. But the advantages of the report were also from some angles its limitations. Because it had to encompass so many perspectives and reflect such a variegated group of people, it could not by its nature be idiosyncratic or individualist. The present account is a reflection from the perspective of a participant-observer in the process.

Reflecting on a university's sesquicentennial celebration is an appropriate context within which to reconsider, in light of Catholic education more generally, Ellis's 1955 essay "American Catholics and the Intellectual Life," since any such conversation is always at some level a conversation with Monsignor Ellis. Even if his name is not invoked at every meeting, any consideration of the academic and intellectual life of Catholic higher education at the turn of the millennium is always also at least in part a colloquy with Ellis's 1955 manifesto. Ellis's diagnosis and exhortation are unavoidable as a touchstone for contemporary analysis and viewpoint. For better or worse, his characterization of the obstacles to American Catholic intellectual achievement touched a nerve and prompted a wave of self-examination unequaled before or since. The contemporary observer still finds arguing with him even after a half century nearly irresistible; his indictment is so sweeping that it provokes a contrarian's instinct to find reasons he was wrong, but the intensity of his dedication to the intellectual ideal and of his conviction that Catholics must live up to it is so compelling that not enlisting in the enterprise seems inconceivable. Fifty years on, what resonance does Ellis's stinging indictment retain? Does it, in retrospect, seem to capture accurately the times it was addressing? Have its boosters or its critics been more thoroughly vindicated by the subsequent half century?

\section{ACTIVE VOICE EXCELLENCE}

Perhaps the most compelling criticism of Ellis's argument is that of the standard against which he measured the success of American Catholic intellectual achievement. His measure of whether American Catholics were achieving intellectually at levels commensurate with their accomplishments in other areas of American life was largely that of the secular academy: How many held degrees from prestigious graduate programs? How many won competitive fellowships? How many were tenured on the faculty of the nation's great (secular) universities (Ellis, 1955)? This standard was both 
entirely plausible for someone in Ellis's time and place and entirely unsuitable for the next generation. It is easy to forget how immediately the postwar context was shaped by the abrupt closing of immigration in the early $1920 \mathrm{~s}$ (Dolan, 1992; Hennesey, 1981). The anti-immigrant animus that prompted the imposition of strict quotas helped create an intensified cohort effect on the generation or two of U.S. Catholics closest to the change (Ahlstrom, 1972). With no new immigrants arriving to highlight their relative assimilation, and with a cultural context that emphasized to an unprecedented degree the exceptionalism and righteousness of the American way of life, the U.S. Catholics who came of age in the generation or two after 1920 were as a cohort under unique pressure to assimilate to American culture (McGreevy, 1996; Tentler, 2004). Questioning American institutions is certainly part of the intellectual heritage of U.S. Catholicism, and it would be inaccurate to characterize Ellis as myopic or unreflective in his adoption of the standards of secular success in measuring the intellectual achievement of Catholic Americans. By his lights, in his times, achievement of these standards was a thing good in itself, evidence of the capacity of Catholics to adapt and to educate their children in the culture in which they found themselves, to live up to a long heritage of intellectual work in which they created the standards.

From the vantage point of 50 years on, however, the work being done by U.S. Catholics in the 1920s and 1930s, while arguably rudimentary, looks compelling and interesting in ways that the dry measures of assessment so valued in Ellis's analysis do not. It is easy to dismiss Furfey's passionate advocacy laughingly as insufficiently sociologically serious, or Gable's design for a Gallery of Living Catholic Writers as cringe-provoking tribalism, but they exhibit a confidence about the power of the Catholic intellectual tradition to lay hold of and transform the disciplines that Ellis's more humble adoption of external standards does not (Furfey, 1936; Gable, 1996). In the 1920s and 1930s, U.S. Catholics were energetic in the redefinition of intellectual work and intellectual excellence in ways that were much more muted by the 1950s. Some of this work is likely best left in the past (Yocum Mize \& Portier, 1997). Some of it, though, can serve as a genuine intellectual resource for thinking through some of the key problems of our own age. To the extent that Ellis's focus on the standards of secular excellence worked to obscure and diminish this distinctively Catholic approach, his critique may have done a long-term disservice.

One effect of his critique is the tendency for Catholic institutions to seek what might be called passive-voice excellence: to seek to be recognized as excellent as a national university or as a center for scholarship. While many forms of external recognition are necessary and appropriate and reflect genuine achievement and the respect of our peers, it is possible that Catholic uni- 
versities and other educational institutions reflect most effectively on the potential distinctiveness of their contributions when they consciously seek active-voice excellence: not simply to be recognized as excellent, but to be excellent. This reformulation encourages Catholic institutions to draw deeply on all their traditions in order to define and seek excellence on their own terms.

The confidence that this search can result in something genuinely exciting seems to me to be re-emerging in Catholic universities, if the University of Dayton's sesquicentennial reflection was any indication. There was a remarkably widespread though not, naturally, universal sense among faculty that there is no contradiction between clear affirmation of Catholic identity and recognizable excellence in research and teaching. This sense derived not from careful compartmentalization, in which academic excellence runs on one track while Catholic character and tradition add a touch of distinctiveness here and there. Instead, a significant number of faculty in a wide array of fields are pursuing research and designing their teaching as responses to a vision of academic excellence and the intellectual life that incorporates explicitly Catholic themes and commitments (Cernera \& Morgan, 2002). The old suspicion that any focus on Catholic and Marianist identity somehow waters down the academic enterprise has by no means entirely dissipated, but it is at least matched - and, in most important ways, probably outmatched - by an enthusiasm for the contribution Catholic traditions of learning and inquiry can make to research and teaching per se, not solely as adjuncts to spiritual growth or catechetical formation. This may well be a major shift, as yet underappreciated.

\section{THE PRAGMATICS OF COMMUNITY}

A related shift, the consequences of which will continue to play out for the foreseeable future, is the changed role of laity in Catholic universities (Gallin, 2000; Schier \& Russett, 2002). Ellis saw this change coming, advocated it, and lived to see much of it take place. Fifty years after his famous analysis, almost all Catholic colleges and universities have revised their governance structures so that the educational institutions are independent of the religious congregations, and so that lay trustees are fully partners in the leadership of the university. The senior administrative leadership at most Catholic colleges and universities is now much more likely to consist of a large majority of laypeople rather than members of the founding religious congregation. As Ellis noted already in 1955, the large majority of faculty at most Catholic universities even then were laity.

The process of reflection on mission and identity in which Catholic colleges and universities have engaged since the 1980s has largely consisted in 
making explicit the meaning of the presence of members of the institution's founding religious communities. When there were large communities of sisters, brothers, and priests on the teaching faculty, when the university's senior leadership consisted primarily of priests or religious, it hardly seemed necessary to ask questions about the university's Catholic identity. The steep decline in the numbers of religious that began in the late 1960s and as yet shows no sign of significant reversal provoked a sense of crisis that seemed to take some people by surprise (Gleason, 1987). Ever since, though not solely for this reason, Catholic colleges and universities have struggled to put into words what made and makes them Catholic. The struggle may be so difficult because putting this particular meaning into words changes it definitively. That is, we could say, at the risk of exaggeration, that what the presence of members of religious congregations contributed to Catholic campuses was distinctively Catholic: embodied in presence, implicit more than explicit, symbolic more than articulated. To shift from embodied presence and lived witness to the description of abstracted values or characteristics is to adopt a different — and perhaps less characteristically Catholic — mode of understanding.

There is a danger here of lapsing into romantic nostalgia. The control of universities by the founding religious orders is not in itself something about which there is any need to be nostalgic. Catholic higher education did not commit itself to academic freedom and genuine faculty governance simply as expedient means to mainstream credibility; these are genuine goods, and there is no reason to think that the move to adopt them was wrong or illtimed or hasty or without sufficient forethought. But though nostalgia is a danger, it is not inevitable, and its possibility should not preclude examining how the declining presence of members of the founding religious communities changed the way Catholic universities think about themselves.

In addressing the question of Marianist character, and of how to sustain Marianist character despite having smaller numbers of vowed Marianists on campus, most discussions over the past 20 years have taken the route of identifying a series of characteristics that distinguish Marianists from other religious congregations, and that make Marianist approaches to education different from others. These discussions have great value in making participants conscious of things they might have taken for granted, in requiring intentional reflection on the connection between Marianist founding commitments and the work of the university today. They can also seem, however, somewhat disconnected from their original context (i.e., the tangible daily reality of Marianist community). Marianist communities are both vowed and lay, a combination that is a crucial part of Marianist heritage. Those with the personal faith commitment who are drawn to the ideal of Marianist lay commu- 
nities are welcomed and supported in that, but the numbers of people involved in such communities will likely always be small. The de facto reality seems to be that for the large majority of people employed at the university, "Marianist" refers primarily to vowed members of the Society of Mary or of the Daughters of Mary Immaculate.

Those who have been around members of vowed religious communities for many years, in some cases for a lifetime, run the risk of forgetting what an anomaly they are in contemporary society. Because they are a familiar aspect of the landscape of Catholic culture, it is easy to overlook what a radical model of alternative living they can appear to be for those raised primarily outside Catholic culture, both Catholic and non-Catholic. Those for whom employment at a Catholic university includes their first sustained contact with members of religious communities not infrequently respond unexpectedly to their growing awareness of Marianist life; they find it powerful, provocative, and occasionally puzzling. This response can be seen to highlight the practices of the Marianist community as a source of insight into what it is that makes a Marianist Catholic university what it is. In at least two areas Catholic universities could more effectively tap into the pragmatics of Marianist community in thinking about how to carry on their charism if the numbers of vowed religious continue to diminish.

First, it would be possible to draw much more confidently on the daily wisdom of religious life in helping students think about how they live together on campus. Ellis (1996) himself, in the address he gave on receiving the University of Dayton's 1986 Marianist Award, noted the role contemporary Marianists could and should play in reviving reflection on moral values in higher education. It is difficult to raise this issue for discussion without being dismissed as naively unaware of the realities of contemporary undergraduate culture. It is true that there is no guarantee that some practical talk about how religious communities function would lead to a dramatic transformation in student life. It is genuinely striking, however, how seldom anyone even thinks to try. Especially for campuses with a largely residential, traditionalage student body, one could reasonably expect that there might be in the more than 1,500 years of monastic tradition some practical advice about how a large and diverse group of people unrelated to each other except by proximity and some basic shared commitments can live mostly harmoniously together. First-year students struggling with full responsibility for their schedules for the first time in their lives might find useful the reflection of religious on how their community schedules help them order their days around their real priorities. Friends who share living space without regularly interacting with each other might be drawn to a description of the power shared meals have to give shape to the day and to provide day-to-day suste- 
nance to relationship. Some frank and detailed advice about how to manage conflict could potentially defuse some of the tensions that infuse relationships in the close quarters of residence hall life.

None of this requires being fooled into thinking that campuses are monasteries, nor that there is a recipe here for turning undergraduate life into some tame utopia. But it might be well worth putting some creative student development minds to work on what might be learned about the pragmatics of community if the lived experience of the religious in our midst was thought of as a practical positive resource as well as a source of abstract inspiration.

There are also potential resources for the leadership of Catholic universities in the experience of the leaders of religious communities. At first glance, this might seem like a dead end for conversation: A religious superior is not a dean or a provost or a president, and virtually everyone involved in contemporary university life would agree that this is appropriate. This response, however, presumes that the only meaningful aspect of leadership within religious communities is hierarchical authority, in which case the discussion would be over - and rightly - before it ever got under way. Setting up the discussion in such zero-sum terms - religious obedience versus academic freedom and faculty autonomy, not an iota of middle ground - obscures some potential resources and preempts some difficult reflection.

The difficult reflection has to do with whether lay Catholics have been evading serious and inspired work on Catholic models of lay leadership since Vatican II. This question exemplifies an interesting irony of the past half century. On the one hand, it was conventional wisdom in the age of Ellis's critique of American Catholic intellectual life that the Church's clerical hierarchy stood in the way of fully-developed lay roles in the Church. On the other hand, at precisely the same time, creative and assertive lay people in a wide variety of fields were reflecting on how their faith informed their professions and how their professions could serve the Church and the world (Avella, 1992; Gleason, 1987; Tentler, 2004). One effect of the cultural shifts surrounding Vatican II was to submerge these currents of explicit Catholic difference in the larger tide of relief at the reconciliation between Church and world. Few Catholics on this side of the conciliar shift would argue that this reconciliation was unneeded or unwelcome. But, 50 years after Ellis's critique and 40 years after the close of Vatican II, it is worth asking whether in the case of models for university administrative leadership the reconciling has tilted rather decisively toward the world. Managerial values are not, by and large, Catholic values, and while no one would dispute the need for professional and effective management and financial structures in the institutions of Catholic higher education, it is hard not to wonder what kind of con- 
ceptual resources might have developed by now if the creative thinking emerging on these issues among Catholic laity in the 1950s had been more consistently sustained.

This is not a call for a Catholic university version of "Jesus, CEO, Ph.D.", nor for additional variations on the servant-leadership theme. It is also not to ignore the extensive scholarship on leadership that people working in Catholic educational institutions have produced in recent decades (Cernera, 2005). It is to suggest that some significant resources remain largely untapped. For example, out of genuine deference and deep humility, members of vowed religious congregations have yielded the administration of their educational institutions to lay collaborators and colleagues without attempting to convey a sense of how their experience as members and leaders of religious communities informed their sense of the life of the university. It would be interesting to see the results of a series of conversations among former and current administrators about whether there is or should be a managerial model peculiarly suited to Catholic institutions. The goal would not be a separatist or even an explicitly counter-cultural stance, but some practical, widely applicable expertise that takes administration of Catholic institutions of higher education as its starting point for reflection. There may well be deep reserves of wisdom here on balancing the temporal and the transcendent, and on leavening bureaucratic fairness and efficiency with thoughtful attentiveness to the personal and the relational, among many other things.

This reflection would not solely be religious or spiritual in focus, though there are surely potential resources for that as well. Instead, one of the current luxuries of contemporary Catholic education is the ability to look back over a record of significant achievement and take our own history as the subject for academic and intellectual research and deliberation. Ellis in 1955 needed too urgently to address what he saw as the failings of that history to turn his intellectual tools to the task of mining intellectual resources. He would, though, likely have had little doubt that the history of U.S. Catholics in the second half of the 20th century offered to a generation of lay Catholic professionals in a wide variety of fields a rich well for reflection on their own experience.

\section{TEMPORALITIES}

These two examples - student life and lay administrative leadership - represent aspects of the legacy of the religious leadership of Catholic higher education on which those involved could draw more explicitly and consciously for tangible practical assets for furthering their work. Another aspect of the legacy of religious leadership is more ambiguous; it could provide a provoca- 
tive alternative vision, it could deepen misunderstanding and division. The witness of simple living is one of the most treasured features of the heritage of religious leadership in Catholic education. While many of the religious congregations that have led Catholic institutions are far from poor in absolute terms, their example of communal living and of the integration of work and life has set a tone on many campuses that may have been even more defining than we have yet realized. In the shift to lay leadership, the abandonment of this witness is taken as a given; what universities seek are competent CEOs, CFOs, and CAOs, to whom they expect to pay market-based salaries and benefits, and whom they expect to evaluate on the basis of the most current managerial principles and assessment practices.

The process of the University of Dayton's Sesquicentennial Conversation included listening to what people from many parts of the campus had to say about the university's identity. One word that emerged from a variety of different discussions was "corporate," used to describe a shift in the university's culture and contrasted unfavorably with a more "Marianist" past. When the draft of our report including this description was published and circulated, we encountered a certain amount of resistance to the use of the term with a negative connotation. Those who used the term in their critique intended it to represent a mindset in which efficiency and revenue generation could too easily trump the human and the personal. In some cases, what was being expressed was regret over the loss of the smaller, more personal university that many of them had known when they first became employees, in some cases decades ago. They recognized both loss and gain, but expressed the need for vigilance that in the attempt to balance out competing concerns the things of greatest importance not be lost. Those who criticized the use of the word corporate to represent this danger seemed not so much to be correcting a lack of balance as rejecting the idea that the word had any negative connotation at all. But understanding the dynamic of this critique reveals an aspect of the shift from religious to lay control that is still playing itself out.

One result of the starkness of this shift may be an intense and largely unarticulated ambivalence about the role of money in university life. It might seem that this ambivalence is distinctive neither to Catholic education nor to the past 50 years. Schools, colleges, and universities have always found it difficult to fund their efforts in a society that relies for much of its success and self-definition on profit-making enterprise. Many education professionals, university faculty among them, harbor long-term suspicions that they could - and perhaps should - have earned more money if they had pursued some aspect of their subject in the private sector. Some have paid a fairly steep personal price by resisting familial or societal expectations in this regard. Most are at least somewhat sensitive to the implication that the uni- 
versity is an ivory tower and that those who make a career there reveal their inability to survive in the hard, cruel world. This makes discussions about university priorities fraught with all kinds of tensions. Everything that faculty value - close contact with good students deeply interested in the subject matter, time for research and study, research materials, advanced classroom technology, space that allows for solitude and silence - costs money, and the money has to come from somewhere. Many faculty, especially those early in their careers or those who come from doctoral work at large research universities to tuition-dependent Catholic universities, are naive about where the money comes from.

At the same time, what they are right about is that the university is a distinctive institution, that the goods it guards are deliberately and rightly not the goods of the marketplace or the opinion poll, and that guarding the enterprise of the university jealously against the dominance of the profit-motive is one of the most sacred duties of the faculty. In this context, the witness of the lives of religious administrators could be seen even by the most secular faculty member as a clear sign that values other than money and worldly success have a place in the highest reaches of the institution. The loss of that sign's clarity may have been inevitable and in some ways beneficial, but an awareness of its effects may help Catholic colleges and universities navigate more effectively the transition to lay leadership while maintaining a distinctive vision. If the embodied witness of religious life provided a powerful symbolic underpinning to the idea of the university per se, what new or newly-enlivened symbols and reaffirmations can play an analogous role for lay leaders and lay faculty? Making this question explicit reveals the absence of ready answers to it and the necessity of active, creative thinking on the subject.

Such thinking may need to start with a question as basic as this: what is a university's money for? It is a question that could be put not only to Catholic universities but to Catholic laity as well. Though many still struggle to makes ends meet, many Catholic colleges and universities are much wealthier than they were in 1955. This is both cause and effect of the rapidity with which Catholics moved through the process of intergenerational social mobility as described above. By the postwar period, Catholics had achieved a level of affluence comparable to and even exceeding that of other American groups and are a major source of the money it will take to finance first-rate Catholic education at all levels, particularly universities (Dolan, 1992; Hennesey, 1981). Financially successful alumni are a key type of partner to whom a Catholic university must look to build endowments, establish chairs, fund research, and build buildings. Which raises the issue of cause and effect in contemporary terms: Could what Catholic universities do with 
their curriculum more actively help develop alumni with a theological understanding of the Church in the modern world that would yield donors who share the distinctive priorities Catholic universities want to have?

Ironically, despite his laments about lay donors, Ellis's vision might be easier to fund. In other words, a tangible and aggressive program to model Catholic achievement after the most prestigious secular universities might attract donors more easily than a more distinctive vision of fostering Catholic intellectual life and asking hard questions about how to orient the social order toward the values of the Gospel. In the achievement of affluence for both persons and institutions, there is a kind of freedom. Catholic universities no longer have to be oriented so single-mindedly toward assimilation and survival. Freedom within a Catholic context is always a freedom for something. This post-conciliar generation may be the acceptable time to ask whether we are using the freedom that affluence affords for the things it should be used for. Ellis's intense desire for Catholics to value and foster intellectual life can be seen as a prophetic recognition that the U.S. context in the 20th century required a primary concern with commercial values, with success on American terms. However, the desire to transcend commercial values and hold them up to the light of Gospel values is itself, possibly, a gift our grandparents have bequeathed us. The contemporary generation owes it to them not to see it as a zero-sum game in which this challenge somehow inherently dishonors their memory, but as the purpose for which the freedom we have on account of them exists.

\section{BELIEF AND PRACTICE}

Addressing this kind of challenge would require familiarity with Catholic theological sensibilities and with Catholic social tradition. Another of the largely implicit changes brought about by the decline in the number of religious has to do with a particular kind of faculty expertise. Sisters, brothers, and priests, by nature of their theological training and their liturgical lives, brought an inescapably interdisciplinary dimension to their teaching and study regardless of their field. In fact, U.S. Catholic intellectual life has been interdisciplinary to an underappreciated extent for much of its history, because so much of the work in it has been done by priests and religious who had at least some training in theology, and also other kinds of education and formation that enabled them to bring to disciplinary questions wide-ranging and independent sensibilities. One person's independence and creativity can be another person's idiosyncrasy and irrelevance, but the basic point holds.

This wide-ranging focus might genuinely have been one obstacle to some of Ellis's goals in an era when specialization was so dominant in defining many fields, especially on the graduate level (Gleason, 1995). Ironically, 
Catholics might want to be very careful about ceding this particular ground, since interdisciplinary work has such conceptual appeal in the contemporary academy, and since there are strong indications that the academy's future development will be in this direction. The shape of the academy is going to continue to change. It looked very different a hundred years ago than it looks today. Some of the forces that reshaped it were unconscious and impersonal, but many of them were the result of human choices and priorities among those who took the lead in re-thinking what teaching and research should be about (Graff, 1987; Shumway, 1994; Turner, 1999). Catholic universities could do much worse than to encourage contemporary Catholic scholars and intellectuals to reflect deeply on the mutual relationship between theology and the other disciplines in light of what a rich and rewarding and transformative 21 st-century academy should look like.

The presence and the percentage of Catholics on the faculty of Catholic universities have been front and center in many national and international discussions about the present and future of Catholic higher education. While it belongs there, Catholic universities and other educational institutions are and should be acutely conscious of the presence of faculty from other religious traditions and others whose personal commitments are resolutely secular. To say that a lively interdisciplinary rapprochement with theology could be an enriching and distinctive line of inquiry for Catholic universities and Catholic intellectual life is not somehow to dismiss secular intellectual inquiry. While it is true that there are aspects of it that are incompatible or locked in mortal combat with Catholic visions of the human person and society, it is also true that this is not an inherent tendency in secular academic inquiry. One of the most significant side effects of pursuing the goals Ellis identified was that in the 1960s and 1970s, Catholic institutions hired large numbers of faculty from first-rate secular universities. In part this was a historical accident. Because the hiring market in so many academic fields was so competitive for so long, many universities were able to hire new young faculty from the very best universities in the country. To an extent probably underappreciated when the change first began to take hold, the ideal of intellectual work particularly at these specific universities was shaped by conscious anti-Catholicism. They presumed a narrative of modernity in which the Church was the model for opposition to academic freedom and intellectual inquiry, the historical obstacle against which Enlightenment rationality and the 19th-century research ideal had to assert and define and defend themselves (McGreevy, 2003). This dispute over the intellectual history of modernity is part of the bedrock on which some of the most painful clashes over the mission and identity of Catholic universities have played themselves out. It is part of the background when faculty worry that renewed emphasis 
on institutional identity and Catholic intellectual tradition will water down the academic quality of education or foreground the soft virtues of personal growth and service at the expense of the rigor of intellectual work and academic excellence.

The excellence of secular universities and the faculty who owe their training to them is its own sort of bedrock, and in order for Catholic universities to be most completely themselves it is essential they integrate both sorts of excellence as they think about the future. What needs integrating is not the "moribund philosophy of materialism and discredited liberalism that have ruled a good portion of the American mind for the better part of a century" (Ellis, 1955, p. 387) over whose passing Ellis rightly rejoiced. The openness, rigor, and conscientious attentiveness to a scholarly ethos-a genuine passion to know and understand the world - that characterize secular universities at their best are gifts in their own right to any university. And to the extent that secular universities stay true to the heritage of the university per se, we might even say that they are furthering a deeply and authentically Catholic heritage in which we are partners and collaborators, not rivals or combatants. If Catholic universities could ever afford to think of themselves as refuges or hermitages, which is doubtful, they certainly cannot afford to think of themselves that way anymore.

The truth of this point - the gifts that faculty with secular training and sensibilities bring to Catholic universities - underscores the difficulty of a final point. During the process of the sesquicentennial conversation, I participated in a discussion with colleagues in which one person made explicitly and passionately the argument that if a university is genuinely Catholic, it would make no difference if not a single member of the faculty were Catholic. I found myself both unable to accept this idea and at first unable to give a good reason why. It was not out of some sentimental attachment having to do with nostalgia for a lost past. It was not because of the pragmatic pastoral need to provide for students' faith lives, because although I was not quite sure where my position was grounded, I knew it was in the nature of the university as university, not in one of its secondary purposes. I finally came to the realization that what was necessary in the presence of Catholic faculty at a Catholic university was the lived reflection on the connection between intellectual life and sacramental practice. There are many principles of Catholic intellectual life and Catholic educational philosophy that can be usefully abstracted from Catholic belief and practice, and these abstractions are essential tools in explaining ourselves to our constituencies and our collaborators. These abstractions emerge from and have living power only to the extent that they remain existentially connected to the sacramental life that gave rise to them to begin with. There is no way to sever Catholic intellectu- 
al life from Catholic sacramental practice and retain Catholic intellectual life in any meaningful and living sense of the term.

In the context of a university community, this connection presents difficulties that will never not be neuralgic and uncomfortable-genuinely uncomfortable, not just in the simplistic sense in which we resolve to make lemons into lemonade. The university's sacramental life must be connected to its intellectual life. As long as Catholic eucharistic practice remains exclusivist, this will hurt feelings and jeopardize some kinds of credibility, and can disintegrate at multiple points into dissension and division. That the point of greatest integration and inclusion from one angle, should be the point of gravest tension and sorrow from another, has tragic dimensions we would do well to name and contemplate, perhaps even do penance for. But the price of leveling or homogenizing the practice in the name of harmony would be too high. Catholic members of the university community who see as a crucial part of their vocation this working out of the relationship between intellectual and sacramental life in the context of the university need to ask for understanding and forgiveness from our collaborators and ask them for their continued presence and assistance in understanding what it means to be the body of Christ in the world. What they get out of this process and this relationship is in some ways for them to decide; it would be presumptuous to tell them how they benefit. But it can be simply said that Catholic universities need them in order to be fully Catholic and for Catholic education to be the gift it can be to the world.

\section{CONCLUSION}

The Sesquicentennial Conversation Task Force agreed to call its 2002 report "Conversing." This title seemed fitting because the verb not only referred to the activity in which the task force had been engaged for over 2 years at that point, but in its earliest usage in English meant "to have one's being, live, dwell, in a place, or among or with people." Universities and churches are very particular sorts of conversations, held among people who dwell among or with one another even when they are not in the same place. Ellis sparked one of the most sustained conversations in the history of American Catholic higher education. He had and still even now has his critics, but he lived to see significant progress in many of the areas that most concerned him. Any of us engaged in reflection on the present and future of Catholic higher education are, if we are lucky, still even now in conversation with him. 


\section{REFERENCES}

Ahlstrom, S. E. (1972). A religious history of the American people. New Haven, CT: Yale University. Avella, S. M. (1992). This confident church: Catholic leadership and life in Chicago, 1940-1965. Notre Dame, IN: University of Notre Dame.

Cernera, A. J. (2005). Lay leaders in Catholic higher education: An emerging paradigm for the twenty-first century. Fairfield, CT: Sacred Heart University.

Cernera, A. J., \& Morgan, O. J. (Eds.). (2002). Examining the Catholic intellectual tradition: Issues and perspectives. Fairfield, CT: Sacred Heart University.

Dolan, J. P. (1992). The American Catholic experience: A history from colonial times to the present. Notre Dame, IN: University of Notre Dame.

Ellis, J. T. (1955). American Catholics and the intellectual life. Thought, 30, 351-88.

Ellis, J. T. (1996). Moral values in higher education. In J. L. Heft (Ed.), Faith and the intellectual life: Marianist Award lectures (pp. 1-9). Notre Dame, IN: University of Notre Dame.

Furfey, P. H. (1936). Fire on the earth. New York: Macmillan.

Gable, M. (1996). The literature of spiritual values and Catholic fiction. Lanham, MD: University Press of America.

Gallin, A. (2000). Negotiating identity: Catholic higher education since 1960. Notre Dame, IN: University of Notre Dame.

Gleason, P. (1987). Keeping the faith: American Catholicism, past and present. Notre Dame, IN: University of Notre Dame.

Gleason, P. (1995). Contending with modernity: Catholic higher education in the twentieth centu$r y$. New York: Oxford University.

Graff, G. (1987). Professing literature: An institutional history. Chicago: University of Chicago.

Hennesey, J. J. (1981). American Catholics: A history of the Roman Catholic community in the United States. New York: Oxford University.

McGreevy, J. T. (1996). Parish boundaries: The Catholic encounter with race in the twentiethcentury urban north. Chicago: University of Chicago.

McGreevy, J. T. (2003). Catholicism and American freedom: A history. New York: W.W. Norton.

Schier, T., \& Russett, C. (Eds.). (2002). Catholic women's colleges in America. Baltimore: Johns Hopkins University.

Shumway, D. R. (1994). Creating American civilization: A genealogy of American literature as an academic discipline. Minneapolis: University of Minnesota.

Tentler, L. W. (2004). Catholics and contraception: An American history. Ithaca, NY: Cornell University Press.

Turner, J. (1999). The liberal education of Charles Eliot Norton. Baltimore: Johns Hopkins University.

University of Dayton. (2002). Conversing: Reflections on the University of Dayton's Catholic and Marianist character in its 150th year-A report from the Task Force on the Sesquicentennial Conversation. Retrieved May 2, 2006, from http://rector.udayton.edu/documents/Character.doc

Yocum Mize, S., \& Portier, W. L. (Eds.). (1997). American Catholic traditions: Resources for renewal. Maryknoll, NY: Orbis Books.

Una M. Cadegan is an associate professor in the Department of History and the director of the American Studies Program at the University of Dayton. Correspondence concerning this article should be sent to Dr. Una M. Cadegan, Department of History, University of Dayton, 300 College Park, Dayton, $\mathrm{OH}$ 45469-1540. 